\title{
START-UP, MODELLING AND SIMULATION OF THE ANAMMOX PROCESS IN A MEMBRANE BIOREACTOR
}

\author{
Grzegorz Cema*, Adam Sochacki, Jakub Kubiatowicz, Piotr Gutwiński, Joanna \\ Surmacz-Górska
}

The Silesian University of Technology, Environmental Biotechnology Department, ul. Akademicka 2, 44-100 Gliwice, Poland

\begin{abstract}
There are certain well-known methods of diminishing concentrations of nitrogen compounds, but they are ineffective in case of nitrogen-rich wastewater with a low content of biodegradable carbon. Partial nitritation followed by anaerobic ammonium oxidation (Anammox) process appear to be an excellent alternative for traditional nitrification and denitrification. This paper presents the feasibility of successful start-up of Anammox process in a laboratory-scale membrane bioreactor (MBR). It was shown that the combination of membrane technology and Anammox process allowed to create a new highly efficient and compact system for nitrogen removal. It was possible to achieve average nitrogen removal efficiency equal to $76.7 \pm 8.3 \%$. It was shown that the start-up period of 6 months was needed to obtain high nitrogen removal efficiency. The applied biochemical model of the Anammox process was based on the state-of-the-art Activated Sludge Model No.1 (ASM 1) which was modified for accounting activity of autotrophs (nitrite-oxidising bacteria and nitrateoxidising bacteria) and anammox bacteria. In order to increase the predictive power of the simulation selected parameters of the model were adjusted during model calibration. Readjustment of the model parameters based on the critically evaluated data of the reactor resulted in a satisfactory match between the model predictions and the actual observations.
\end{abstract}

Keywords: activate sludge model, Anammox, computer simulation, modelling, nitrogen removal

\section{INTRODUCTION}

Partial nitrification/Anammox process is a promising method of removing nitrogen from ammoniumrich wastewater. In this treatment process, ammonium is partially oxidised to nitrite by ammonium oxidising bacteria (AOB) and subsequently, anammox bacteria convert the remaining ammonium and nitrite to nitrogen gas (Strous et al., 1998). The main advantages of this process compared to conventional nitrification/denitrification are: low sludge production, a decrease of aeration costs by almost $60 \%$ (only half of the ammonia is oxidised to nitrite in the nitritation process without further oxidation to nitrate), and no need for external organic carbon source addition (Anammox process) (Mulder, 2003; De Clippeleir et al., 2011). Low sludge production is another factor that contributes to substantially lower operation costs compared to conventional denitrification systems. However, practical implementation of the Anammox process is still limited by its long start-up periods due to very low growth rates and biomass yields of the involved biomass (Fernandez et al., 2008) combined with the sensitivity of microorganisms to inhibitory concentrations of some compounds that are often present in industrial effluents. In order to reduce the duration of the start-up period and provide better conditions to implement the Anammox process, reactors with good biomass retention are used including biofilm reactors (Moving Bed Biofilm Reactors (MBBR), Rotating Biological Contactors

*Corresponding author, e-mail: grzegorz.cema@polsl.pl 
$(\mathrm{RBC})$ ), reactors with granular sludge or sequencing batch reactors (SBR) and Membrane Bioreactors (MBR).

Due to its low growth rate, Anammox biomass demands lengthy and often expensive experiments to study its behaviour in wastewater treatment reactors. The time and cost of research can be markedly reduced by combining real-world experiments involving the Anammox process (on various scales) with computer simulation studies using mathematical models. A mathematical model is a simplification of reality, therefore the study of Anammox process for wastewater treatment purposes may be represented by adapting already existing mechanistic models, such as the IWA Activated Sludge Models (ASMs), which are widely accepted and can be reasonably adjusted to mimic the process. For almost three decades the ASM family models (Henze et al;, 2000) have been widely used for both research and design, thus they appear to be a firm basis for the Anammox process model, which was corroborated in several studies (eg. Dapena-Mora et al., 2004; Hao et al., 2002a; Hao et al., 2004; van Hulle, 2005). Hitherto, most of the modelling studies were carried out for biofilm systems (e.g. Hao et al., 2002a; 2002b; 2004; 2005; Koch et al., 2000) and only several studies focused on suspended biomass system (Dapena-Mora, 2004; Jones, 2007; van Hulle, 2005). There were two main goals of this study: (i) to develop the Anammox process in a MBR reactor, and (ii) to apply the extended ASM1 model (DapenaMora et al., 2004; Henze et al., 1987; van Hulle, 2005) to simulate the Anammox process in MBR.

\section{MATERIALS AND METHODS}

The lab-scale MBR, operated as a continuous stirred tank reactor (CSTR), with a working volume of $36 \mathrm{~L}$ used in this study is presented in Fig. 1. The ultrafiltration flat-sheet membrane module was fully immersed in the reactor. As a membrane cartridge the Kubota type 203, with a total surface area $0.1 \mathrm{~m}^{2}$ and nominal pore size of $0.4 \mu \mathrm{m}$, was used. Membrane sheet is ultrasonic-welded on both surfaces of the membrane panel and it is made of chlorinated polyethylene. The reactor was equipped with an aquarium heater with a thermostat to keep temperature constant above $30^{\circ} \mathrm{C}$ and with a vertical stirrer to ensure proper mixing. The reactor was provided with synthetic wastewater by a peristaltic pump and the same way permeate was sucked out. An effluent pump was connected with the flat sheet membrane cartridge.

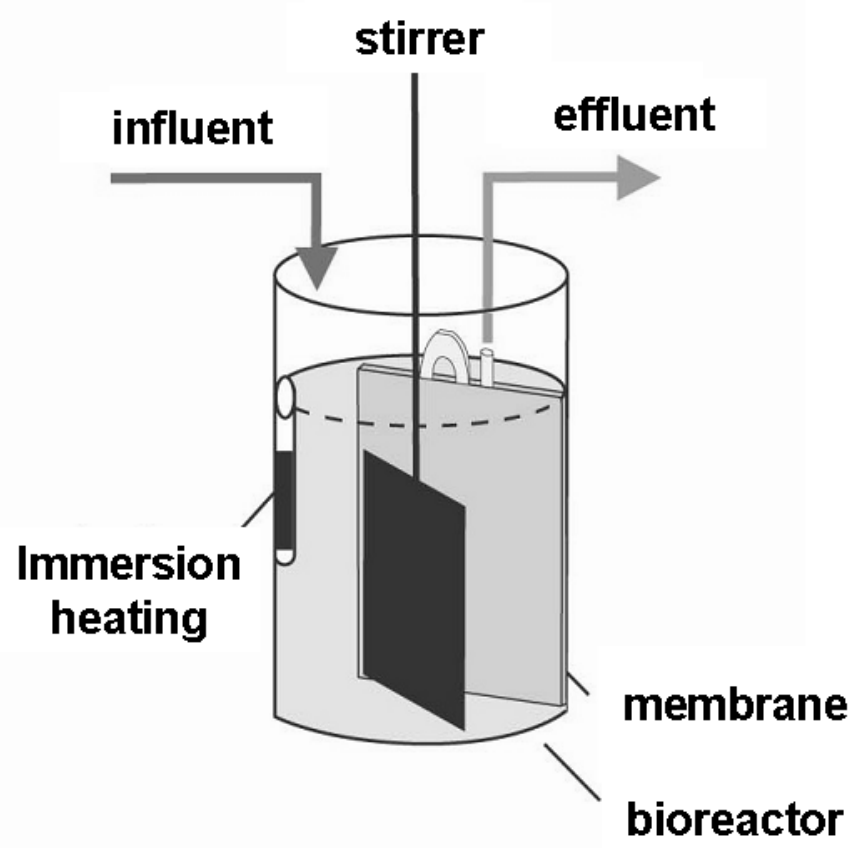

Fig. 1. Set-up of the lab-scale MBR modelled in the study 
Trigo et al. (2006) proved that the precipitation of calcium phosphate in the reactor contributes to the reduction of Anammox bacteria activity. The use of membrane modules resulted in the accumulation of inorganic solids in the reactor from precipitation of salt from the medium originally used by van de Graff et al. (1996). Therefore, it was necessary to change the concentration of calcium and phosphorus in the synthetic medium. For this reason the synthetic wastewater was prepared according to van de Graff et al. (1996) and modified according to Trigo et al. (2006). Table 1 presents the composition of the synthetic wastewater used in this study.

Table 1. Characteristics of the influent medium

\begin{tabular}{|c|c|c|}
\hline Parameter & $\begin{array}{c}\text { Concentration }\left[\mathrm{g} \mathrm{m}^{-3}\right] \\
\text { This study and Trigo et al. } \\
(2006)\end{array}$ & $\begin{array}{c}\text { Concentration }\left[\mathrm{g} \mathrm{m}^{-3}\right] \\
\text { Van de Graff et al. (1996) }\end{array}$ \\
\hline$\left(\mathrm{NH}_{4}\right)_{2} \mathrm{SO}_{4}$ & 330 & 330 \\
\hline $\mathrm{NaNO}_{2}$ & 345 & 345 \\
\hline $\mathrm{KHCO}_{3}$ & 500 & 500 \\
\hline $\mathrm{KH}_{2} \mathrm{PO}_{4}$ & 5.4 & 54 \\
\hline $\mathrm{MgSO}_{4}$ & 300 & 300 \\
\hline $\mathrm{CaCl}_{2}$ & 4.5 & 180 \\
\hline $\mathrm{FeSO}$ & 5 & 5 \\
\hline $\mathrm{EDTA}$ & 5 & 5 \\
\hline
\end{tabular}

The reactor was inoculated with nitrifying sludge from the Zabrze Wastewater Treatment Plant and additionally, $250 \mathrm{ml}$ of Anammox sludge coming from a lab-scale RBC (Rotating Biological Contactor) reactor with Anammox process in operation was added.

During the research period, samples were taken from the influent, effluent and activated sludge mixed liquor. The efficiency of the biological treatment was followed in terms of the general parameters such as: COD (dichromate method), ammonia, nitrite and nitrate nitrogen (Merck tests). Moreover, the process was monitored by measurements of the following parameters: flow rate, $p H$, temperature, dissolved oxygen and biomass concentration in the bulk liquid. Free ammonia and free nitrous acid concentrations were calculated according to Anthonisen et al. (1976).

Fluorescent in situ Hybridisation (FISH) was performed in order to determine nitrifiers and anammox bacteria. In situ hybridisation was conducted as described by Daims et al. (2005). A detailed description of the methodology, sequences and target sites used can be found in Cema et al. (2007).

\subsection{Modelling the MBR (hydrodynamic and clarification model)}

Modelling of the Anammox process and related processes in this work was performed within the simulation environment WEST (Wastewater Treatment Plant Engine for Simulation and Training) Software Package version 3.7.5 (Vanhooren et al., 2003). The WEST simulator was selected because of the in-house experience, direct application to various wastewater treatment processes and the possibility of edition of the default models. The membrane bioreactor (MBR) was implemented by using a model of continuously stirred tank reactor (CSTR) linked with an ideal point-settler model. This settler model was used to functionally mimic the behaviour of the real-world membrane. Thus, a parameter $\left(f_{N S}\right)$ non-settleable fraction of the sludge in the settler was set to zero to simulate complete retention of biomass by the membrane (Fig. 2). 


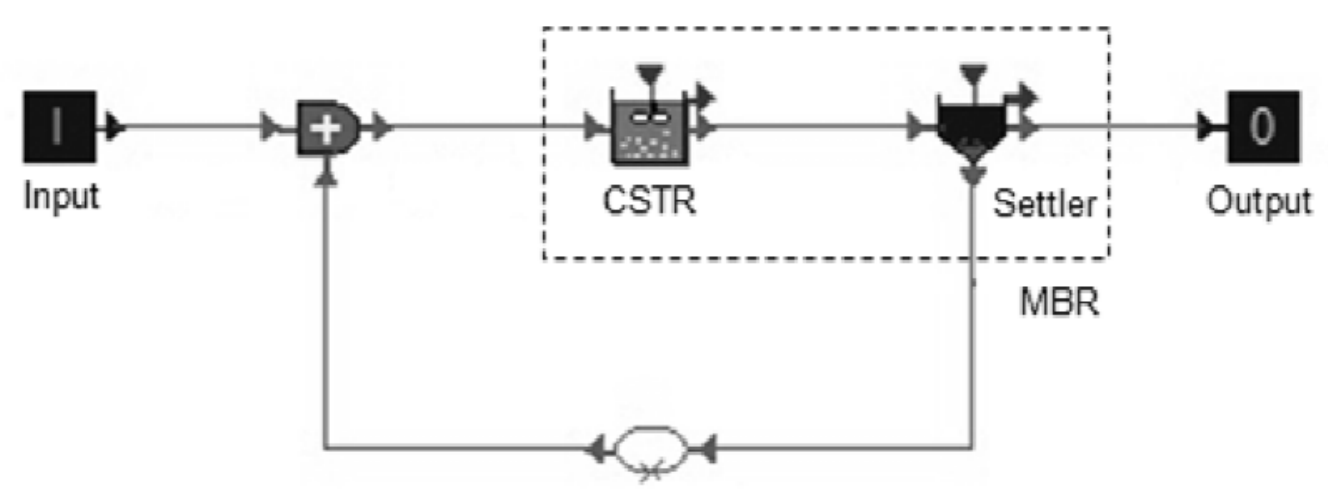

Fig. 2. Implementation of the MBR configuration in the modelling environment WEST

\subsection{Biokinetic model - ASM1 extension for anaerobic ammonia oxidation}

The Anammox model was implemented according to the research of Dapena-Mora et al. (2004) and Van Hulle (2005). These authors extended state-of-the-art ASM1 (Henze et al., 1987) with a 2-step nitrification-denitrification and the Anammox process. To allow for this distinction new groups of organisms were added to the modified biokinetic model. ASM1 nitrifiers were divided into ammonium oxidising organisms $\left(X_{N H}\right)$ and nitrite oxidising organisms $\left(X_{N O}\right)$, whose growth is represented as follows by the Monod terms Eqs. (1-2):

for nitritation

$$
\rho_{N H \text { growth }}=\mu_{N H}^{M A X}\left(\frac{S_{O}}{K_{O, N H}+S_{O}}\right)\left(\frac{S_{N H}}{K_{N H, N H}+S_{N H}}\right) X_{N H}
$$

and nitratation

$$
\rho_{\text {NOgrowth }}=\mu_{N O}^{M A X}\left(\frac{S_{O}}{K_{O, N O}+S_{O}}\right)\left(\frac{S_{N O 2}}{K_{N O 2, N O}+S_{N O 2}}\right) X_{N O}
$$

where $\mu_{N H}^{M A X}$ and $\mu_{N O}^{M A X}$ are maximum growth rates $\left(\mathrm{d}^{-1}\right)$ of $\mathrm{X}_{N H}$ and $\mathrm{X}_{N O}$, respectively; $\mathrm{S}_{O}$ is dissolved oxygen (DO) concentration $\left(\mathrm{gO}_{2} \mathrm{~m}^{-3}\right) ; S_{N H}$ and $S_{\mathrm{NO} 2}$ is concentration of ammonia and nitrite, respectively $\left(\mathrm{g} \mathrm{m}^{-3}\right) ; K_{O, N H}, K_{O, N O}, K_{N H, N H}, K_{N O 2, N O}$ are half-saturation coefficients $\left(\mathrm{gO}_{2} \mathrm{~m}^{-3}\right)$ for DO (the two former), ammonia and nitrite (the two latter) of ammonia oxidizers and nitrite oxidizers; $X_{N H}$ and $X_{N O}$ is the concentration of biomass $\left(\mathrm{g} \mathrm{m}^{-3}\right)$.

In order to model the Anammox process the modified model includes Anammox biomass $\left(X_{A N}\right)$, whose growth is described by Monod kinetics as follows in Eq. (3):

$$
\rho_{\text {ANgrowth }}=\mu_{A N}^{M A X}\left(\frac{K_{O, A N}}{K_{O, A N}+S_{O}}\right)\left(\frac{S_{N O 2}}{K_{N O 2, A N}+S_{N O 2}}\right)\left(\frac{S_{N H}}{K_{N H, A N}+S_{N H}}\right) X_{A N}
$$

Inhibition of $X_{A N}$ by $S_{N O 2}$ was not included in Equation (3). The Anammox process which occurs only when DO is absent and in the model it is switched by a switching function Equation (4) in the kinetic equation (3) (Henze et al., 2000):

$$
\left(\frac{K_{O, A N}}{K_{O, A N}+S_{O}}\right)
$$


The two-step denitrification is described by the equations where either nitrite Equation (5) or nitrate Equation (6) as an electron acceptor:

$$
\begin{aligned}
\rho_{\text {Hgrowth }(\mathrm{NO} 2)} & =\mu_{H}^{\mathrm{MAX}}\left(\frac{K_{O, H}}{K_{O, H}+S_{O}}\right)\left(\frac{S_{S}}{K_{S, H}+S_{S}}\right)\left(\frac{S_{\mathrm{NO} 2}}{K_{\mathrm{NO} 2, \mathrm{H}}+S_{\mathrm{NO} 2}}\right)\left(\frac{S_{\mathrm{NO} 2}}{S_{\mathrm{NO} 2}+S_{\mathrm{NO} 3}}\right) \eta_{\mathrm{NO} 2} X_{H} \\
\rho_{\text {Hgrowth }(\mathrm{NO} 3)} & =\mu_{H}^{M A X}\left(\frac{K_{O, H}}{K_{O, H}+S_{O}}\right)\left(\frac{S_{S}}{K_{S, H}+S_{S}}\right)\left(\frac{S_{\mathrm{NO} 3}}{K_{\mathrm{NO}, \mathrm{H}}+S_{\mathrm{NO} 3}}\right)\left(\frac{S_{\mathrm{NO} 3}}{S_{\mathrm{NO} 2}+S_{\mathrm{NO} 3}}\right) \eta_{\mathrm{NO} 3} X_{H}
\end{aligned}
$$

Heterotrophic activity, especially denitrification, is not directly coupled with the Anammox process and autotrophic nitrogen removal, but some studies indicate that heterotrophic bacteria are present and active in autotrophic systems with no external COD source (Van Hulle, 2005). In this model the decay process of bacteria is modelled according to the death-regeneration concept as proposed in ASM1. Dead biomass releases inert particulate matter $\left(X_{P}\right)$ and slowly biodegradable organic substrate $\left(X_{S}\right)$. The $\mathrm{X}_{\mathrm{P}}$ fraction is removed from the system with the excess sludge and $X_{S}$ is hydrolysed to $S_{S}$. Decay rate is equal under aerobic, anoxic and anaerobic conditions and no electron acceptor is utilised. The decay rate for any type of biomass is described by a first-rate equation:

$$
\rho_{\text {decay }}=b_{?} X_{?}
$$

This death-regeneration approach used in the modified ASM1 is based on the fact that heterotrophic organisms were found to be active in autotrophic reactors without an addition of external COD source, which can be explained by death-regeneration, and not by endogenous respiration, which was applied in ASM3. Although, in this study, no biodegradable compounds were added to the influent, it was assumed that a value of $2 \mathrm{~g} \mathrm{COD} \mathrm{m}^{-3}$ would reflect the composition of tap water used for medium preparation and biodegradable substrate originating from EDTA in the trace element solution (DapenaMora et al., 2004). The temperature dependency of all the rate constants was modelled using Arrhenius equation:

$$
k(T)=k\left(T_{r}\right) e^{\theta(T-T r)}
$$

$T_{r}$ is the reference temperature $(293 \mathrm{~K})$ and $\Theta$ is the Arrhenius constant $\left(\mathrm{K}^{-1}\right)$ for each process (Van Hulle, 2005). This equation described temperature effect within the range of $20-40^{\circ} \mathrm{C}(273-293 \mathrm{~K})$, which was relevant in this study.

The stoichiometry of the Anammox process in the applied model is presented in Table 2 in Petersen matrix format (Depena-Mora et al., 2004; Van Hulle, 2005). The default value of the Anammox biomass yield $\left(Y_{A N}\right)$ was $0.159\left(\mathrm{gCOD} \mathrm{gN}^{-1}\right)$, the $N$ content in the Anammox biomass $\left(i_{N X B A}\right)$ was 0.0562 $\left(\mathrm{gN} \mathrm{gCOD}^{-1}\right)$, fraction of $X_{P}$ in dead biomass $\left(f_{P}\right)$ was $0.08\left(\mathrm{gCOD} \mathrm{gCOD}^{-1}\right)$ and $N$ content in $X_{P}\left(i_{N X P}\right)$ was $0.06\left(\mathrm{gN} \mathrm{gCOD}^{-1}\right)$.

Table 2. Stoichiometric matrix for the Anammox in the applied model

\begin{tabular}{|c|c|c|c|c|c|c|c|c|}
\hline & \multicolumn{7}{|c|}{ Component } \\
\hline Process & $\begin{array}{c}\mathrm{X}_{\mathrm{S}} \\
{\left[\mathrm{gCOD} \mathrm{m}^{-3}\right]}\end{array}$ & $\begin{array}{c}\mathrm{X}_{\mathrm{AN}} \\
{\left[\mathrm{gCOD} \mathrm{m}{ }^{-3}\right]}\end{array}$ & $\begin{array}{c}\mathrm{X}_{\mathrm{P}} \\
\left.[\mathrm{gCOD} \mathrm{m})^{-3}\right]\end{array}$ & $\begin{array}{c}\mathrm{S}_{\mathrm{NO} 2} \\
{\left[\mathrm{gN} \mathrm{m}^{-3}\right]}\end{array}$ & $\begin{array}{c}\mathrm{S}_{\mathrm{NO} 3} \\
{\left[\mathrm{gCOD} \mathrm{m}^{-3}\right]}\end{array}$ & $\begin{array}{c}\mathrm{S}_{\mathrm{N} 2} \\
{\left[\mathrm{gN} \mathrm{m}^{-3}\right]}\end{array}$ & $\begin{array}{c}\mathrm{S}_{\mathrm{NH}}{ }^{1} \\
{\left[\mathrm{gN} \mathrm{m}^{-3}\right]}\end{array}$ & $\begin{array}{c}\mathrm{S}_{\mathrm{ALK}}{ }^{2} \\
{\left[\mathrm{~mol} \mathrm{~m}^{-3}\right]}\end{array}$ \\
\hline $\begin{array}{c}\text { Growth } \\
\text { of } \mathrm{X}_{\mathrm{AN}}\end{array}$ & 1 & & $-1.52-\frac{1}{Y_{A N}}$ & 1.52 & $\frac{2}{Y_{A N}}$ & $-i_{N X B A}-\frac{1}{Y_{A N}}$ & $-\frac{i_{N X B A}}{14}$ \\
\hline $\begin{array}{c}\text { Decay } \\
\text { of } \mathrm{X}_{\mathrm{AN}}\end{array}$ & $1-f_{p}$ & -1 & $f_{p}$ & & & & $i_{N X B A}-f_{p} i_{N X P}$ & $\frac{1}{14}\left(i_{N X B A}-f_{P} i_{N X P}\right)$ \\
\hline
\end{tabular}

1 dinitrogen; 2 alkalinity 
The fractionation of nitrogenous components in influent was straightforward as only two fractions were present in the real influent, this is, ammonium $\left(S_{N H}\right)$ and nitrite $\left(S_{N O 2}\right)$. The concentration of these compounds in the model input was identical to the real-world reactor feed taking into consideration different phases of the experiment. The applied model uses the same components, kinetics, stoichiometry and notation as the models of Dapena-Mora et al. (2004) and van Hulle (2005). The default values of the kinetic and stoichiometric parameters were based on the values suggested by Volcke (2006). These parameters were used as first estimates prior to adjustment of the model parameters.

\section{RESULTS AND DISCUSSION}

In order to maintain the Anammox process in the MBR, it was necessary to provide conditions favourable for growth of the desirable bacteria. The bacteria cultivation took place at the temperature above $30^{\circ} \mathrm{C}$, at a very low dissolved oxygen concentration (around $0.1 \mathrm{gO}_{2} \mathrm{~m}^{-3}$ ) and at average $\mathrm{pH}-$ value in the influent corrected and maintained around 8 . In the influent medium a very low content of biodegradable organic carbon was maintained in order to prevent an overgrowth of heterotrophs. Moreover, the nitrite-to-ammonium ratio in the influent to the reactor was around 1:1 which is close to the stoichiometric value of 1.32:1 (Strous et al., 1998).

As nitrite nitrogen is a potential inhibitor for the Anammox process its concentration in the reactor was kept at a low level below $20 \mathrm{~g} \mathrm{~m}^{-3}$. During the first 80 days of the experiment, nitrogen removal efficiency was very weak, and only minor oxidation of ammonium to nitrite was observed. After 80 days nitrogen removal efficiency started to increase, which resulted in a drop of nitrite concentration in the effluent. For this reason the concentration of inorganic nitrogen in the inflow to the reactor was gradually increased from 50 to $600 \mathrm{gN} \mathrm{m}^{-3}$ (Fig. 3). At the same time the nitrogen load to the reactor was increased from 33 to $167 \mathrm{gN} \mathrm{m}^{-3} \mathrm{~d}^{-1}$. The maximum observed nitrogen removal efficiency was equal to $87.4 \%$ and at the same time very intensive gas production in the reactor was observed. A stable and high nitrogen removal efficiency equal to $76.7 \pm 8.3 \%$ on average was observed from 240 days of experiment.

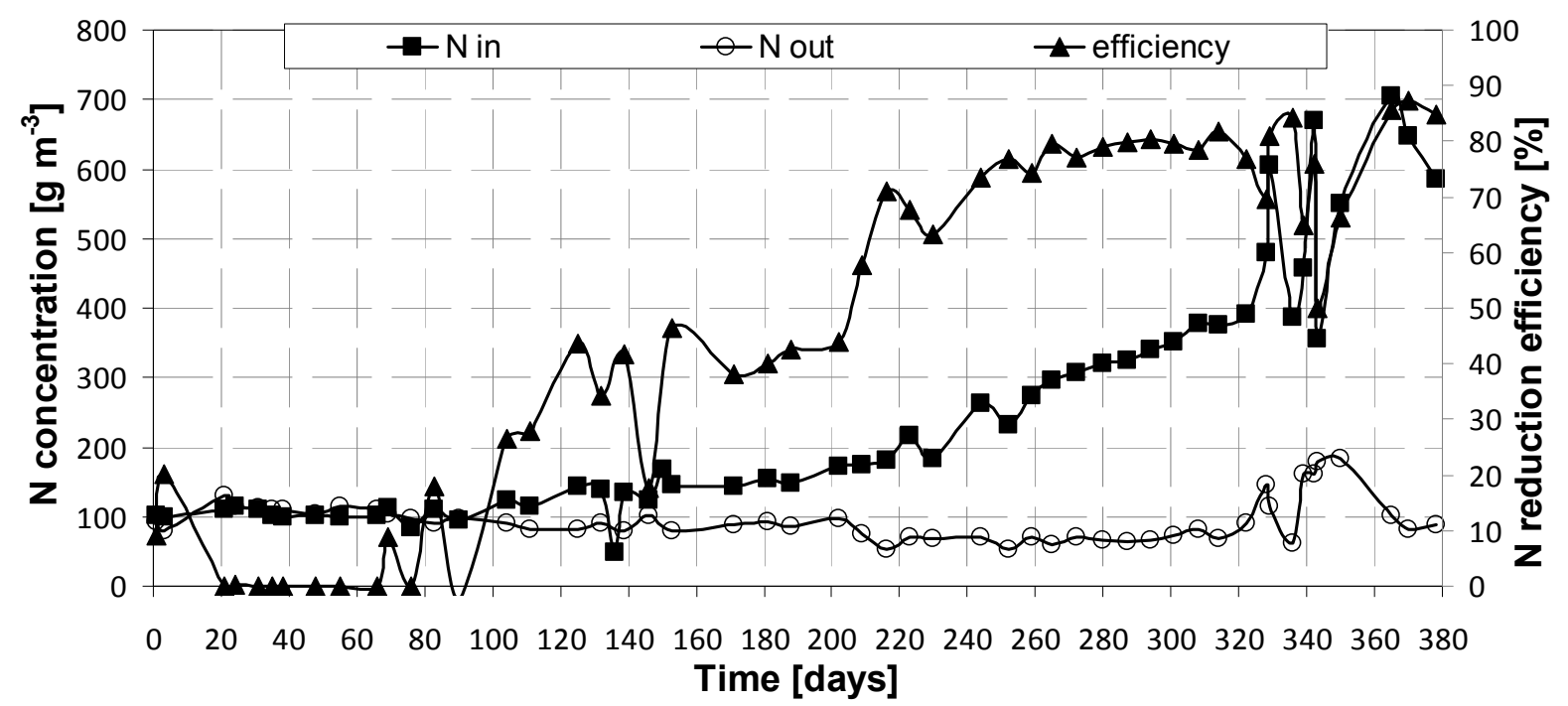

Fig. 3. Total inorganic nitrogen in the influent and effluent from the Anammox reactor and nitrogen removal efficiency

The ratio of nitrate production to ammonium consumption $\left(\mathrm{NO}_{3}{ }^{-} / \mathrm{NH}_{4}{ }^{+}\right)$, as well as the ratio between nitrite conversion and ammonium conversion $\left(\mathrm{NO}_{2}{ }^{-} / \mathrm{NH}_{4}{ }^{+}\right)$gave some additional information about the 
process stoichiometry (Fig. 4). The average conversion ratio of nitrite and ammonium $\left(\mathrm{NO}_{2}{ }^{-} / \mathrm{NH}_{4}{ }^{+}\right)$ during the whole research period was $1.25 \pm 1.15$ and was slightly lower than these values found by Strous and co-workers (1998). Additionally, the conversion ratio between nitrate production and ammonium conversion was $0.31 \pm 0.83$, which was higher than the stoichiometric value of 0.26 . However, from the onset of nitrogen removal on the $220^{\text {th }}$ day, the average ratio was equal to $1.82 \pm$ 1.00 and $0.20 \pm 0.32$ for $\mathrm{NO}_{2}{ }^{-} / \mathrm{NH}_{4}{ }^{+}$and $\mathrm{NO}_{3}{ }^{-} / \mathrm{NH}_{4}{ }^{+}$ratios, respectively. These data suggested that the Anammox process was predominant in the system. However, some activity of denitrifying bacteria can be also expected due to lower production of nitrate and higher conversion of nitrite than that stemming from stoichiometry.

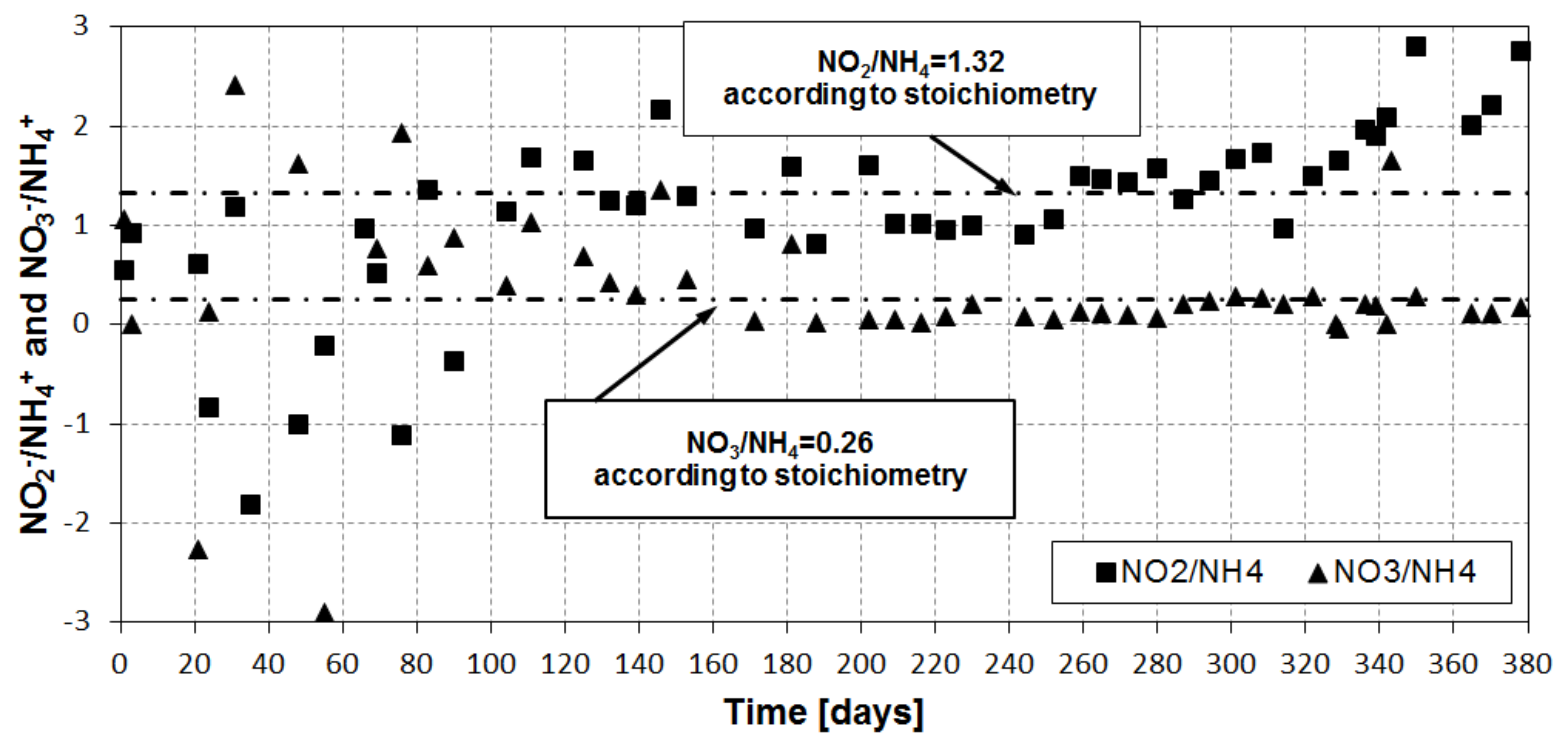

Fig. 4. Conversion ratio of nitrite and ammonium and between nitrate production and ammonium conversion (negative values - nitrite build-up took place)

Using FISH test it was confirmed that bacteria belonging to Brocadia anammoxidans and/or Kuenenia stuttgartiensis were present in the reactor and proved occurrence of the Anammox reaction in the reactor.

\subsection{Model calibration}

Model calibration is the most crucial step in the entire modelling procedure (Makinia et al., 2002). According to Mikosz (2009) a selection of the most important parameters during sensitive analysis may allow to shorten time used for model calibration and to increase the prediction power of a model. The purpose of the model calibration was to obtain a set of parameters, which would allow to use the model as an acceptable predictive tool for the investigated real-world reactor. The Anammox model was calibrated in a step-wise process: (i) simulation with default model parameters, (ii) sensitivity analysis, (iii) critical selection of model parameters to be adjusted, (iv) simulation with adjusted model parameters, (v) evaluation of the simulation results. In this procedure the most sensitive parameters are determined by sequential modifications leading to their identification. Sensitivity analysis is commonly used to identify the model parameters that have the most far-reaching effect on the model variables (Melcer et. al., 2003; Mikosz, 2009). In the context of sensitivity analysis the term 'parameter' is used in a general sense referring not only to model kinetics and stoichiometry but also to influent characteristics and operational variables. Sensitivity analysis can help to identify those parameters that can be estimated with the most accuracy and to exclude those that have a negligible effect on model variables (Melcer et. al., 2003). It was assumed that the least possible number of parameter values should be changed to obtain reasonable fits (Makinia et al., 2002). The sensitivity analysis was 
performed by a positive change of each individual parameter one at a time by 10 per cent of an initial value of each parameter.

Based on the sensitivity analysis the following parameters were selected to be adjusted: half-saturation constants $\left(K_{\mathrm{NO}, A N}\right.$, half-saturation constant for $\mathrm{N}^{-\mathrm{NO}_{2}}$ of Anammox bacteria; $K_{O, N H}$, half-saturation constant for $\mathrm{O}_{2}$ of ammonium oxidisers; $K_{N H, A N}$, half-saturation constant for $\mathrm{N}^{-\mathrm{NH}_{4}}$ of Anammox bacteria) and yield of Anammox biomass $\left(Y_{A N}\right)$. Calibration strategy consisted in the adjustment of the most important model parameters to minimise the differences between the values obtained by simulation and experimental data. Changes in the parameters were evaluated on the basis of the three variables of the model: $S_{N H}$ (concentration of total ammonia nitrogen), $S_{\mathrm{NO} 2}$ (total concentration of nitrite nitrogen) and $S_{\mathrm{NO} 3}$ (nitrate nitrogen concentration). Kinetic and stoichiometric parameter values which changed compared to the suggested default values during model calibration are listed in Table 3.

Table 3. Parameter values adjusted during model calibration

\begin{tabular}{|c|c|c|c|}
\hline Parameter & Unit & Default value & Adjusted value \\
\hline$K_{N O 2, A N}$ & $\mathrm{gN} \mathrm{m}^{-3}$ & 0.05 & 2.00 \\
\hline$K_{O, N H}$ & $\mathrm{gO}_{2} \mathrm{~m}^{-3}$ & 0.6 & 0.7 \\
\hline$K_{N H, A N}$ & $\mathrm{gN} \mathrm{m}^{-3}$ & 0.07 & 0.08 \\
\hline$Y_{A N}$ & $\mathrm{gCOD} \mathrm{gN}^{-1}$ & 0.159 & 0.150 \\
\hline
\end{tabular}

$K_{N O 2, A N}$ was increased from 0.05 to $2.00 \mathrm{gN} \mathrm{m}^{-3}$ and $K_{O, N H}$ was slightly increased from 0.6 to $0.7 \mathrm{gO}_{2} \mathrm{~m}^{-3}$ in order to increase the simulated effluent nitrite nitrogen concentration. $K_{N H, A N}$ was increased from

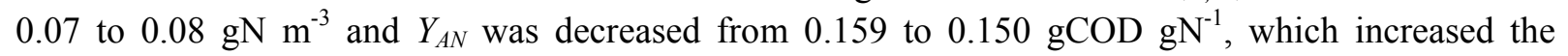
simulated effluent ammonium nitrogen concentration and enhanced the model prediction power. All the adjusted values of kinetic and stoichiometric parameters in this study are within a range reported in the literature (Makinia, 2010). The adjusted values of $K_{N O 2, A N}$ and $Y_{A N}$ used in this study were previously used by Koch et al. (2000) to model a biofilm system used for autotrophic denitrification at a temperature of $20^{\circ} \mathrm{C}$, which is $11-12^{\circ} \mathrm{C}$ lower than in the reactor modelled and simulated in the described experiment. This may suggest that temperature distribution in the reactor was lower or not uniform, or both, within the confines of the reactor. The increased values of half-saturation constants may also follow from diffusion limitation for specific compounds within the flocs.

The calibration results for calibration of the model are depicted in Figure 5 where the measured and simulated effluent ammonia, nitrite and nitrate nitrogen concentrations are shown. There are some significant discrepancies between the predicted and measured nitrite nitrogen concentration values prior to calibration. After the calibration the predictive capacity of the model considerably increased and the match between the measured and simulated effluent concentrations was acceptable.

\subsection{Model verification}

Model calibration is followed by its validation. According to Makinia (2010) the fundamental aim of validation is to compare predictions by the calibrated model with real data to reveal similarities and differences between model prediction and measured results. It should be stressed that the data set used for validation must be different from the data set used for calibration. The model is considered to be validated when the differences are acceptable in order to achieve the goal of simulations. One of the most important principles of model verifications is to keep all the previously adjusted parameters constant so that obtained results are credible (Sochacki et al., 2009).

The results of the model verification are presented in Figure 6. The results show that the calibrated model is able to predict effluent ammonia, nitrite and nitrate nitrogen concentrations using influent 
from substantially different periods. To corroborate that the model predictions were compared with the measurement data.

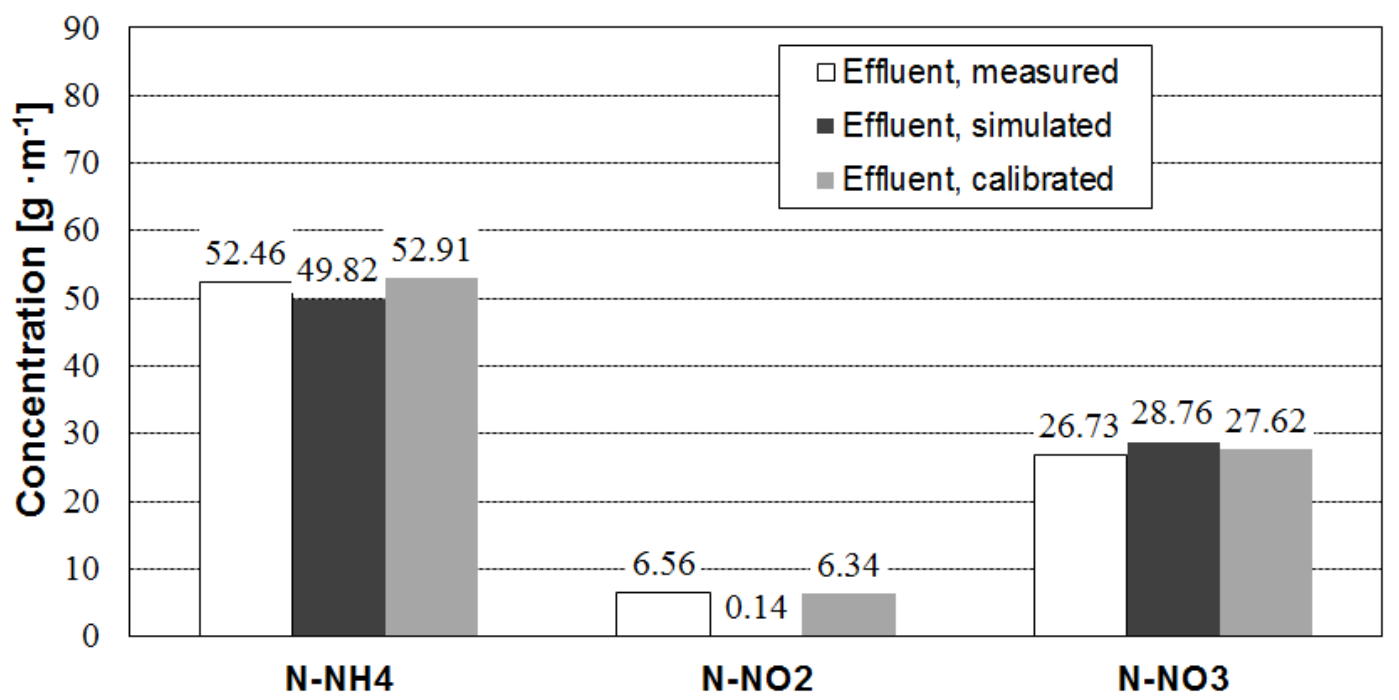

Fig. 5. Comparison of measured and simulated effluent ammonia, nitrite and nitrate nitrogen concentrations during model calibration

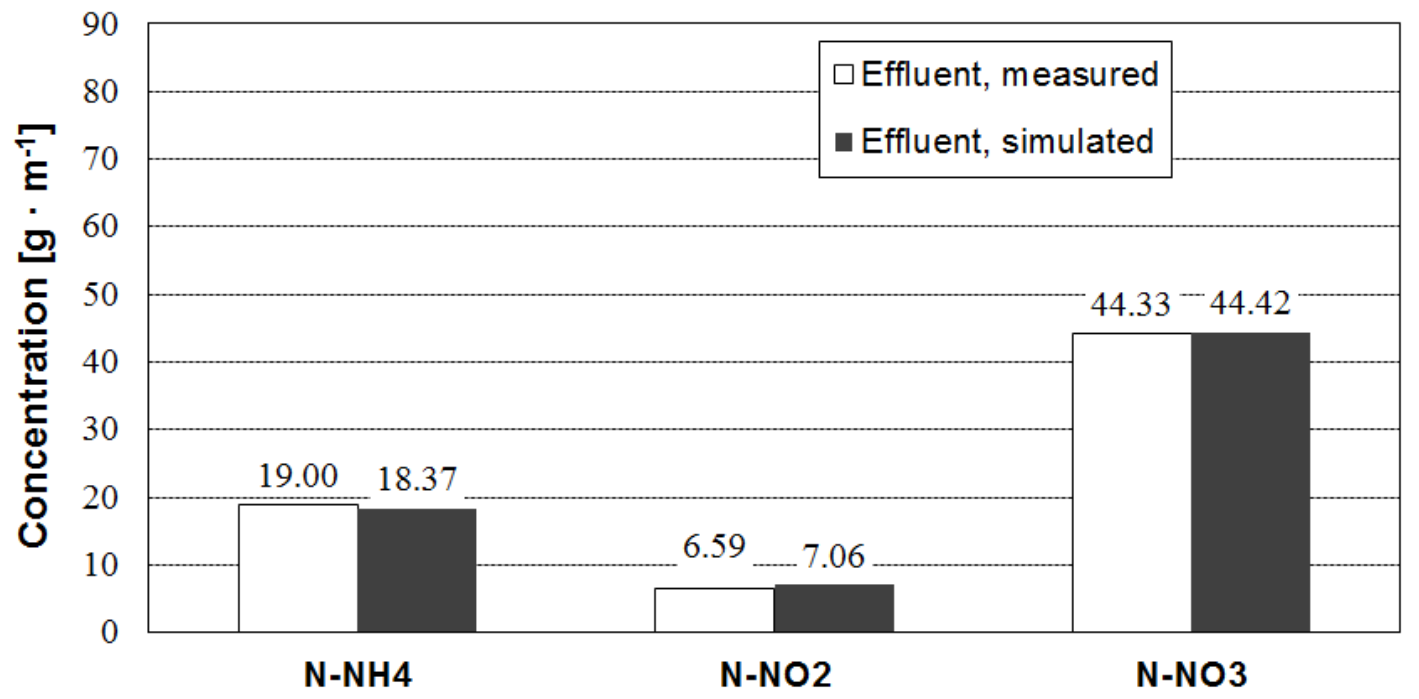

Fig. 6. Comparison of measured and simulated effluent ammonia, nitrite and nitrate nitrogen concentrations during model validation

\section{CONCLUSIONS}

The conducted experiments proved that retention of biomass in MBR and long sludge age open up possibility to implement the Anammox process, and this reactor is an interesting alternative for biofilm systems. At a temperature above $30^{\circ} \mathrm{C}$, dissolved oxygen concentration below $0.3 \mathrm{gO}_{2} \mathrm{~m}^{-3}$ and at very low contents of biodegradable organic compounds, stable and high nitrogen removal efficiency equal to $76.7 \pm 8.3 \%$ on average was achieved from 240 days of the experiment. However, the research confirmed that very long time, over six months, is needed for the implementation of the Anammox process. The use of membrane bioreactor did not result in shortening the time needed to start-up of the Anammox process. It is also consistent with the observations of Trigo et al. (2006) who reported the 
bacterial doubling time equal to 18 days and the results are comparable with those obtained in other systems (Fux, 2003; Li et al., 2004).

Based on the obtained simulations result, the following conclusions can be derived:

- The study indicates that anaerobic ammonium oxidation model can be successfully developed using the Activated Sludge Model No. 1 extended with the Anammox process.

- An acceptable match between the model predictions and the measured data during validation indicates that the model has appropriate prediction power. The model is able to predict effluent ammonia, nitrite and nitrate concentrations.

We dedicate this work to the late Professor Krzysztof W. Szewczyk, an outstanding scholar and dear colleague, feeling grateful for his scientific inspirations and unfailing courtesy.

This study is supported by Polish Ministry of Science and Higher Education, grant no. N N523 751740. The authors wish to thank Marek Tarlowski for his aid in laboratory experiments.

\section{SYMBOLS}

$b \quad$ decay coefficient for biomass, $\mathrm{d}^{-1}$

$f_{N S} \quad$ non-settleable fraction of the sludge, -

$f_{P} \quad$ fraction of particulate products arising from biomass decay in dead biomass, gCOD gCOD ${ }^{-1}$

$i_{N X B A} \quad$ nitrogen content in the Anammox biomass, $\mathrm{gN} \mathrm{gCOD}^{-1}$

$i_{N X P} \quad$ nitrogen content in particulate products arising from biomass decay, $\mathrm{gN} \mathrm{gCOD}^{-1}$

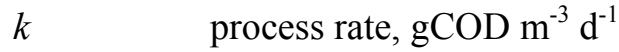

$k(T) \quad$ is process rate (growth rate, decay rate or hydrolysis rate) at the actual temperature $(T)$, $\mathrm{g} \mathrm{m}^{-3} \mathrm{~d}^{-1}$

$k\left(T_{r}\right) \quad$ is process rate (growth rate, decay rate or hydrolysis rate) at the reference temperature $\left(T_{r}\right), \mathrm{g} \mathrm{m}^{-3} \mathrm{~d}^{-1}$

$K_{N H, A N} \quad$ ammonium half-saturation constant of Anammox bacteria, $\mathrm{gN} \mathrm{m}^{-3}$

$K_{N H, N H} \quad$ ammonium half-saturation coefficient for ammonium oxidizers, $\mathrm{gN} \mathrm{m}^{-3}$

$K_{N O 2, A N} \quad$ nitrite half-saturation constant Anammox bacteria, $\mathrm{gN} \mathrm{m}^{-3}$

$K_{N O 2, N O} \quad$ nitrite half-saturation coefficient for nitrite oxidizers, $\mathrm{gN} \mathrm{m}^{-3}$

$K_{N O 3, H} \quad$ nitrate half-saturation coefficient for heterotrophic biomass, $\mathrm{gN} \mathrm{m}^{-3}$

$K_{O, H} \quad$ oxygen half-saturation coefficient for heterotrophic biomass, $\mathrm{g}(-\mathrm{COD}) \mathrm{m}^{-3}$

$K_{O, N H} \quad$ oxygen half-saturation coefficient for ammonium oxidizers, $\mathrm{g}(-\mathrm{COD}) \mathrm{m}^{-3}$

$K_{O, N O} \quad$ oxygen half-saturation coefficient for nitrite oxidizers, g(-COD) $\mathrm{m}^{-3}$

$K_{S, H} \quad$ readily biodegradable organic substrate half-saturation coefficient for heterotrophic biomass, $\mathrm{gCOD} \mathrm{m}^{-3}$

$S_{A L K} \quad$ alkalinity, $\mathrm{mol} \mathrm{m}^{-3}$

$\mathrm{S}_{\mathrm{NH}} \quad$ ammonium concentration, $\mathrm{gN} \mathrm{m}^{-3}$

$S_{N H} \quad$ concentration of ammonia, $\mathrm{gN} \mathrm{m}^{-3}$

$S_{\mathrm{NO} 2} \quad$ concentration of nitrite, $\mathrm{gN} \mathrm{m}^{-3}$

$S_{\mathrm{NO} 3} \quad$ is concentration of nitrate, $\mathrm{g} \mathrm{m}^{-3}$

$S_{O} \quad$ dissolved oxygen concentration, $\mathrm{g}(-\mathrm{COD}) \mathrm{m}^{-3}$

$S_{S} \quad$ concentration of readily biodegradable organic substrate, $\mathrm{g} \mathrm{m}^{-3}$

$T_{r} \quad$ actual temperature, $\mathrm{K}$

$T_{r} \quad$ reference temperature, $\mathrm{K}$

$X \quad$ biomass concentration, $\mathrm{gCOD} \mathrm{m}^{-3}$ 
$X_{A N} \quad$ concentration of Anammox biomass, gCOD m ${ }^{-3}$

$X_{H} \quad$ concentration of heterotrophic biomass, $\mathrm{gCOD} \mathrm{m}^{-3}$

$X_{N H} \quad$ concentration of ammonium oxidizing organisms, $\mathrm{gCOD} \mathrm{\textrm {m } ^ { - 3 }}$

$X_{N O} \quad$ concentration of nitrite oxidizing organisms, $\mathrm{gCOD} \mathrm{m}^{-3}$

$X_{P} \quad$ concentration of particulate products arising from biomass decay, $\mathrm{gCOD} \mathrm{m}^{-3}$

$X_{S} \quad$ concentration of slowly biodegradable organic substrate, gCOD m${ }^{-3}$

$Y_{A N} \quad$ Anammox biomass yield, ${\mathrm{gCOD} \mathrm{gN}^{-1}}^{-1}$

Greek symbols

$\Theta \quad$ the Arrhenius constant, $\mathrm{K}^{-1}$

$\mu_{H}^{M A X} \quad$ is maximum growth rate of heterotrophic biomass, $\mathrm{d}^{-1}$

$\mu_{A N}^{M A X} \quad$ is maximum growth rate of the Anammox biomass, $\mathrm{d}^{-1}$

$\mu_{N H}^{M A X} \quad$ maximum growth rate of ammonium oxidizing organisms, $\mathrm{d}^{-1}$

$\mu_{N O}^{M A X} \quad$ maximum growth rate of nitrite oxidizing organisms, $\mathrm{d}^{-1}$

\section{Abbreviations}

ASM1 Activated Sludge Model No.1

ASMs Activated Sludge Models

IWA International Water Association

WEST Wastewater Treatment Plant Engine for Simulation and Training

\section{REFERENCES}

Anthonisen A.C., Loehr R.C., Prakasam T.B.S., Srinath E.G., 1976. Inhibition of nitrification by ammonia and nitrous acid. J. Water Pollut. Control Fed., 48, 835-852.

Cema G., Wiszniowski J., Żabczyński S., Zabłocka-Godlewska E., Raszka A., Surmacz-Górska J., 2007. Biological nitrogen removal from landfill leachate by deammonification assisted by heterotrophic denitrification in rotating biological contactor (RBC). Water Sci. Technol., 55, 35-42. DOI: 10.2166/wst.2007.239.

Daims H., Stoecker K., Wagner M., 2005. Fluorescence in situ hybridization for the detection of prokaryotes, In: Osborn A.M., Smith C.J. (Eds.), Advanced Methods in Molecular Microbial Ecology. Bios-Garland, Abingdon, UK., 213-239.

Dapena-Mora A., Van Hulle S.W.H., Campos J.L., Mendez R., Vanrolleghem P.A. and Jetten M., 2004. Enrichment of Anammox biomass from municipal activated sludge: experimental and modeling results. $J$. Biotechnol., 79, 1421-1428. DOI: 10.1002/jctb.1148.

De Clippeleir H., Yan X., Verstraete W., Vlaeminck S.E., 2011. OLAND is feasible to treat sewage-like nitrogen concentrations at low hydraulic residence time. Proceedings of the IWA/WEF Nutrient Recovery and Management 2011, 9 - 12 January 2011, Miami, Florida, 1264-1274.

Fernández I., Vázquez-Padín J.R., Mosquera-Corral A., Campos J.L., Méndez R., 2008. Biofilm and granular systems to improve Anammox biomass retention. Biochem. Eng. J., 42, 308-313. DOI: 10.1016/j.bej.2008.07.011.

Fux C., 2003. Biological nitrogen elimination of ammonium-rich sludge digester liquids. PhD Thesis, Swiss Federal Institute of Technology Zurich. DISS. ETH NO. 15018.

Hao X., Heijnen J.J., van Loosdrecht M.C.M., 2002b. Sensitivity analysis of a biofilm model describing a onestage completely autotrophic nitrogen removal (CANON) process. Biotechnol. Bioeng., 77, 266-277. DOI: 10.1102/bit.10105.

Hao X., Heijnen J.J., Van Loosdrecht MC.M., 2002a. Model-based evaluation of temperature and inflow variations on a partial nitrification-ANAMMOX biofilm process. Water Res., 36, 4839-4849. DOI: 10.1016/S0043-1354(02)00219-1.

Hao X.-D. and van Loosdrecht MC.M., 2004. Model-based evaluation of COD influence on a partial nitrificationAnammox biofilm (CANON) process. Water Sci. Technol., 49(11-12), 83-90. 
Henze M., Grady C.P.L. Jr., Gujer W., Marais G.V.R., Matsuo T., 1987. Activated sludge model No. 1. IAWQ Scientific and Technical Report No. 1, London, UK.

Henze M., Gujer W., Mino T., van Loosdrecht M., 2000. Activated sludge models ASM1, ASM2, ASM2d and ASM3. IWA Scientific and Technical Report No. 9. IWA Publishing, London, UK.

Koch G., Engli K., van der Meer J.R. and Siegrist H., 2000. Mathematical modeling of autotrophic denitrification in a nitrifying biofilm of a rotating biological contactor. Water Sci. Technol., 41, 191-198.

Li X., Zen G., Rosenwinkel K.H., Kunst S., Weichgrebe D., Cornelius A., Yang Q., 2004. Start up of deammonification process in one single SBR system. Water Sci. Technol., 50, 1-8.

Makinia J., 2010. Mathematical modeling and computer simulation of activated sludge systems. IWA Publishing, London, UK.

Makinia J., Swinarski M., Dobiegala E. (2002). Experiences with computer simulation at two large wastewater treatment plants in northern Poland. Water Sci. Technol. 45, 209-218.

Mikosz J., 2009. Efect of biomass characterization in komputer simulation of BNR processes. Proceedings of a Polish-Swedish-Ukrainian Seminar, Stockholm, Sweden, September 23-25. 2009.

Mulder A., 2003. The quest for sustainable nitrogen removal technologies. Water Sci. Technol., 48, 67-75.

Sochacki A., Knodel J., Geißen S.-U., Zambarda V., Miksch K., Bertanza G., 2009. Modelling and simulation of a municipal WWTP with limited operational data. Proceedings of a Polish-Swedish-Ukrainian Seminar, Stockholm, Sweden, September 23-25, 2009.

Strous M., Heijnen J., Kuenen J. G., Jetten M.S.M., 1998. The sequencing batch reactor as a powerful tool for the study of slowly growing anaerobic ammonium-oxidizing microorganisms. Appl. Microbiol. Biotechnol., 50, 589-596. DOI: $10.1007 / \mathrm{s} 002530051340$.

Trigo C., Campos J.L., Garrido J.M., Mendez R., 2006. Start-up of the Anammox process in a membrane bioreactor. J. Biotechnol., 126, 475-487. DOI: 10.1016/j.jbiotec.2006.05.008.

van de Graaf A.A., de Bruijn P., Robertson L.A., Jetten M.S.M., Kuenen J.G., 1996. Autotrophic growth of anaerobic ammonium-oxidizing micro-organisms in a fluidized bed reactor. Microbiology, 142, 2187-2196. DOI: $10.1099 / 13500872-142-8-2187$.

Van Hulle S., 2005. Modelling, simulation and optimisation of autotrophic nitrogen removal processes. $\mathrm{PhD}$ Thesis, Ghent University, Belgium.

Vanhooren H, Meirlaen J, Amerlinck Y, Claeys F, Vangheluwe H and Vanrolleghem P.A., 2003. WEST: Modelling biological wastewater treatment. J. Hydroinform., 5, 27-50.

Volcke E.I.P., 2006. Modelling, analysis and control of partial nitritation in a SHARON reactor. PhD thesis, Ghent University, Belgium, 300. 